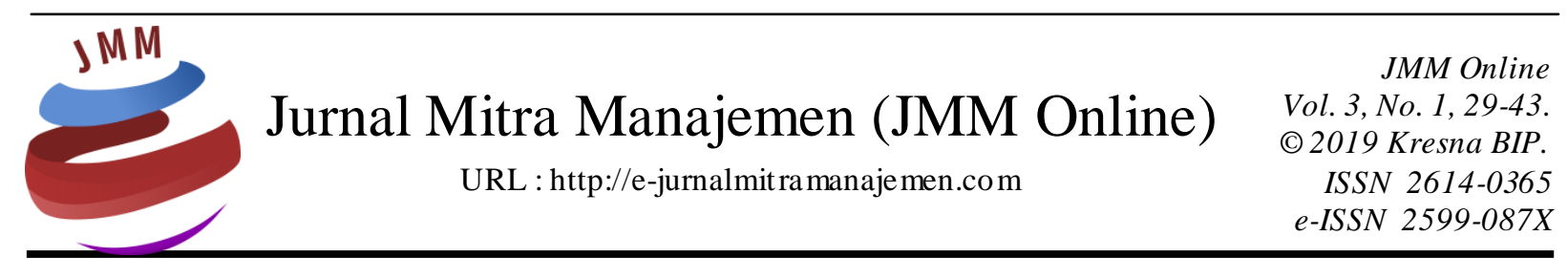

\title{
PERAN MODAL SOSIAL SEBAGAI MEDIATOR LITERASI KEUANGAN DAN INKLUSI KEUANGAN DI KOTA PADANG
}

\author{
Nabila Safira ${ }^{1)}$, Andrieta Shintia Dewi ${ }^{2)}$ \\ Universitas Telkom
}

INFORMASI ARTIKEL

Dikirim : 11 Desember 2018

Revisi pertama : 14 Januari 2019

Diterima : 18 Januari 2019

Tersedia online : 31 Januari 2019

Kata Kunci : Literasi Keuangan, Inklusi Keuangan, Modal Sosial, Analisis Mediasi, Masyarakat Kota Padang

Email : nabilaasafira@gmail.com ${ }^{1)}$, andrieta@telkomuniversity.ac.id ${ }^{2)}$
ABSTRAK

Tingkat literasi keuangan di Kota Padang terbilang rendah, sedangkan angka inklusi keuangan di Kota Padang cukup tinggi, hal ini menandakan bahwa masyarakat yang menggunakan produk lembaga jasa keuangan sudah banyak, tetapi belum semuanya paham dengan produk yang mereka ambil, mereka belum memiliki cukup pengetahuan mengenai apa yang mereka gunakan. Oleh karena itu Otoritas Jasa Keuangan (OJK) perlu melakukan perluasan edukasi dan sosialisasi guna meningkatkan angka literasi keuangan di Kota Padang. Dengan adanya modal sosial diharapkan akan menjadi mediator dalam peningkatan literasi dan inklusi keuangan. Penelitian ini bertujuan untuk mengetahui peran modal sosial sebagai mediator hubungan antara literasi keuangan dan inklusi keuangan. Selain itu, penelitian ini juga meneliti efek tidak langsung dari literasi keuangan pada inklusi keuangan.

Populasi dari penelitian ini adalah seluruh penduduk Kota Padang yang berjumlah 5.382.077 jiwa pada tahun 2018. Pengambilan sampel dari penelitian ini menggunakan teknik non-probability sampling dengan jumlah sampel sebanyak 400 sampel. Penelitian ini mengadopsi dan menggunakan Sobel dan Kenny \& Baron tes untuk menguji pengaruh mediasi modal sosial dalam hubungan antara literasi keuangan dan inklusi keuangan. Hasil dari penelitian ini menemukan bahwa terbukti modal sosial secara partial mampu memediasi hubungan antara literasi keuangan dan inklusi keuangan di Kota Padang. 


\section{PENDAHULUAN \\ Latar Belakang}

Menurut OJK (Otoritas Jasa Keuangan, 2016) Literasi Keuangan adalah rangkaian proses atau aktivitas untuk meningkatkan pengetahuan, keyakinan dan keterampilan konsumen maupun masyarakat luas sehingga mereka mampu mengelola keuangan dengan baik serta kebutuhan dasar bagi setiap orang agar terhindar dari masalah keuangan. Literasi keuangan memiliki tujuan jangka panjang untuk seluruh golongan masyarakat seperti meningkatkan literasi seseorang yang sebelumnya less literate bahkan not literate menjadi well literate dan meningkatkan jumlah pengguna produk dan penyedia jasa keuangan, seperti service yang tawarkan oleh perbankan ataupun lembaga-lembaga masyarakat. Dalam Kamus Besar Bahasa Indonesia ( KBBI ), kata Inklusi berarti termasuk atau terhitung. Oleh sebab itu inklusi keuangan merajuk pada jumlah orang yang menjadi nasabah atau pengguna jasa keuangan di Indonesia. Jenis-jenis jasa keuangan yang ada seperti penyimpanan uang, transfer, peminjaman uang, investasi, asuransi dan lain sebaginya. Berdasarkan data dari survey nasional literasi dan inklusi keuangan 2016 oleh OJK adalah sebagai berikut:

\section{Gambar 1. Tingkat Literasi Keuangan Dan Inklusi Keuangan Di Provinsi Sumate ra Barat dan Indonesia Tahun 2016 (Dalam Persen)}

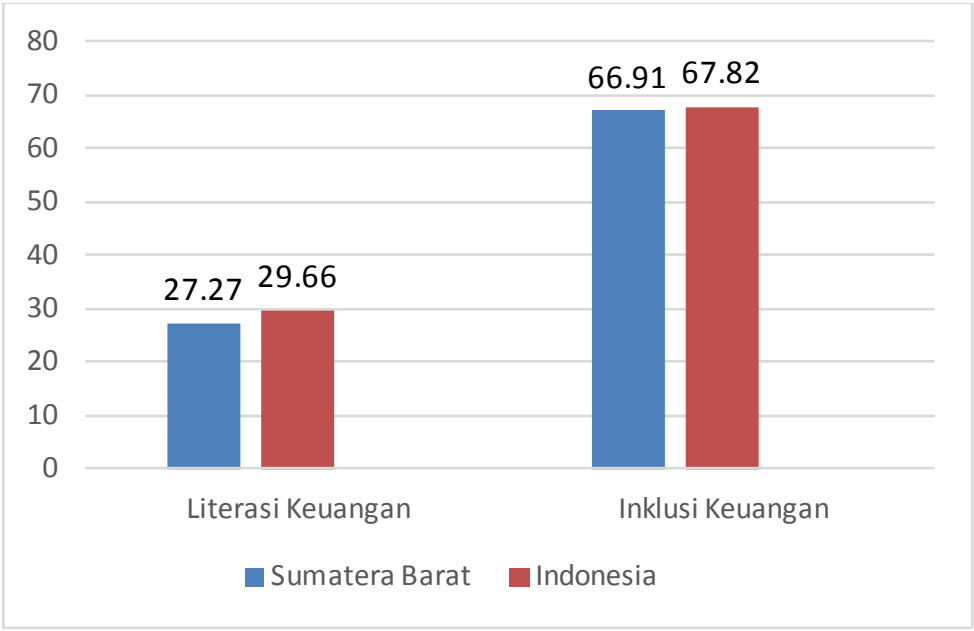

Sumber : OJK (2016)

Berdasarkan gambar 1, tingkat literasi keuangan dan inklusi keuangan di Sumatera Barat masih dibawah rata-rata Indonesia secara keseluruhan. Dari tingkat inklusi keuangan di Sumatara Barat sebesar 66.91\% menunjukkan bahwa posisi Provinsi Sumatera Barat memiliki indeks yang cukup bagus jika dibandingkan dengan target yang ingin di capai pemerintah pada tahun 2019 nanti yaitu mencapai 35\% (Padangkita.com, 2018). Namun Otoritas Jasa Keuangan (OJK) terus melakukan berbagai kegiatan untuk mendorong perluasan program Inklusi Keuangan guna mendukung sasaran Strategi Nasional Keuangan Inklusi (SNKI) yakni tingkat literasi keuangan sebesar 75\% pada akhir 2019. (www.ojk.go.id, Otoritas Jasa Keuangan, 2016). Tingkat literasi dan inklusi keuangan masyarakat Sumatera Barat masih dibawah angka nasional, sehingga perlu perluasan edukasi dan sosialisasi yang lebih massif mengenai industri keuangan di masyarakat Sumatera Barat dan Kota Padang khususnya. Dari perbedaan tingkat inklusi dan literasi di Sumatera Barat umumnya dan 
di Kota Padang khususnya, artinya masyarakat yang menggunakan produk lembaga jasa keuangan sudah banyak, tetapi belum semuanya paham dengan produk yang tersedia, mereka belum memiliki cukup pengetahuan mengenai apa yang mereka gunakan. Kondisi tersebut menjadi tidak ideal karena penggunaan produk keuangan hendaknya diimbangi dengan pengetahuan yang cukup mengenai lembaga jasa keuangan. OJK telah menciptakan berbagai program dalam rangka meningkatkan literasi keuangan dan inklusi keuanga seperti mengadakan program "Rangking 1" untuk pelajar di Sumatera Barat dan berkerja sama dengan beberapa Bank dalam menciptakan produk perbankan untuk pelajar yaitu "simPel" atau simpanan pelajar (sumbar.antaranews.com,2018)

Modal sosial adalah tentang solidaritas, kepercayaan diri, dan memfasilitasi dalam menjalankan suatu bisnis, yang merupakan faktor yang berasal dari hubungan sosial yang melibatkan keluarga, teman, rekan kerja, dan lain-lain (Felicio et.al. 2014). Modal sosial berperan sebagai perekat yang mengikat semua orang dalam masyarakat atau sebagai sumber mendapatkan informasi, menjalin kerja sama dan sebagainya (Yanti, 2017). Peran modal sosial dalam pengusaha "Rubik Ganepo" dan program Laku Pandai yang diciptakan oleh OJK merupakan beberapa contoh peran modal sosial yang membantu masyarakat dalam menyelesaikan permasalahannya mengenai produk dan jasa keuangan.

Mengingat adanya peran modal sosial dan penting nya peningkatan literasi keuangan dan inklusi keuangan di Kota Padang, maka peneliti bermaksud untuk meneliti "Peran Modal Sosial Sebagai Mediator Literasi Keuangan Dan Inklusi Keuangan Di Kota Padang". Beberapa penelitian sebelumnya berusaha menjelaskan tentang peran modal sosial sebagai mediator pada kaum muda di Indonesia secara umum, tetapi penelitian tersebut masih tidak menjadikan Kota Padang sebagai objek dalam penelitian.

\section{Rumusan Masalah}

Berdasarkan latar belakang yang telah dijabarkan sebelumnya, maka dapat dirumuskan pertanyaan penelitian sebagai berikut :

1. Apakah literasi keuangan memiliki efek yang signifikan terhadap modal sosial?

2. Apakah modal sosial memiliki efek yang signifikan pada inklusi keuangan?

3. Apakah modal sosial memediasi hubungan antara literasi keuangan dan inklusi keuangan?

\section{Tujuan Penelitian}

Berdasarkan latar belakang dan rumusan masalah yang telah di jabarkan sebelumnya maka tujuan penelitian ini sebagai berikut :

1. Untuk mengetahui apakah literasi keuangan memiliki efek yang signifikan pada modal sosial,

2. Untuk mengetahui apakah modal sosial memiliki efek yang signifikan terhadap inklusi keuangan,

3. Untuk mengetahui apakah modal sosial mampu memediasi hubungan antara literasi keuangan dan inklusi keuangan. 


\section{KAJIAN PUSTAKA Inklusi Keuangan}

Menurut Bank Indonesia (2018) Kebijakan keuangan inklusif adalah suatu bentuk pendalaman layanan keuangan (financial service deepening) yang ditujukan kepada masyarakat in the bottom of the pyramid untuk memanfaatkan produk dan jasa keuangan formal seperti sarana menyimpan uang yang aman (keeping), transfer, menabung maupun pinjaman dan asuransi. The Financial Action Task Forces (2011) dalam Saputa \& Dewi (2017) mendefinisikan inklusi keuangan adalah tentang menyediakan akses ke lembaga keuangan yang memadai secara aman, nyaman, dan terjangkau layanan keuangannya untuk kelompok rentan yang kurang beruntung dan lainnya termasuk masyarakat berpenghasilan rendah, orang pedesaan dan tidak berdokumen, yang telah terlayani atau dikecualikan dari sektor keuangan formal. Singkatnya, Inklusi keuangan (financial inclusive) merujuk pada jumlah orang yang menjadi nasabah atau pengguna jasa keuangan di Indonesia. Jasa keuangan itu ada banyak jenisnya, missal, menyimpan uang yang aman, transfer, pinjaman, investasi dan asuransi.

\section{Lite rasi Keuangan}

Dalam hal finansial, literasi keuangan dapat diartikan sebagai kecakapan atau kesanggupan dalam hal keuangan.Carolynne L J Mason \& Richard M SWilson (2000) dalam Rasyid (2012) mengatakan literasi finansial didefinisikan sebagai kemampuan seseorang untuk mendapatkan, memahami dan mengevaluasi informasi yang relevan untuk pengambilan keputusan dengan memahami konsekuensi finansial yang ditimbulkannya. Hung et.al (2009) mendefinisikan bahwa literasi keuangan sebagai pengetahuan tentang konsep-konsep ekonomi dan keuangan dasar, serta kemampuan untuk menggunakan pengetahuan (knowledge) dan keterampilan (skill) keuangan lainnya dalam mengelola sumber daya keuangan secara efektif untuk kesejahteraan keuangan. Literasi Keuangan juga memberikan manfaat yang besar bagi sektor jasa keuangan. Lembaga keuangan dan masyarakat saling membutuhkan satu sama lain sehingga semakin tinggi tingkat Literasi Keuangan masyarakat, maka semakin banyak masyarakat yang akan memanfaatkan produk dan layanan jasa keuangan.

\section{Modal Sosial}

Modal sosial merupakan bagian-bagian dari organisasi sosial seperti kepercayaan umum di dalam sebuah masyarakat, norma, dan jaringan yang dapat meningkatkan efisiensi masyarakat dengan memfasilitasi tindakan-tindakan yang terkoordinasi dan memungkinkan terjalinnya kerjasama. Modal sosial hanya dapat dibangun ketika tiap individu belajar dan mau belajar mempercayai individu lain (Yanti, 2017). Kamukama \& Natamba (2013) mengatakan bahwa modal sosial dikenal sebagai dasar model pinjaman kelompok karena menciptakan jaminan sosial, yang mengkompensasi kurangnya aset material dalam pengaturan pemberian pinjaman kelompok. Semakin banyak, modal sosial tercipta akan menghasilkan penciptaan peminjam yang dapat memenuhi syarat, jaringan yang kuat dalam kelompok, kepercayaan, pengawasan rekan kerja dan mekanisme penjaminan, arusinformasi yang lebih baik antara pemberi pinjaman dan peminjam. 


\section{Model Konseptual Penelitian}

Secara garis besar, penelitian ini akan melakukan :

1. Analisis pengaruh literasi keuangan terhadap peran modal sosial,

2. Analisis pengaruh modal sosial terhadap inklusi keuangan,

3. Analisis efek modal sosial memediasi hubungan antara litera si keuangan dan inklusi keuangan

Kerangka pemikiran pada gambar 2 merupakan replikasi dari penelitian yang dilakukan oleh Bongomin et.al (2016). Dalam penelitian Bongomin et.al (2016) menemukan bahwa modal sosial sangat berperan dalam hubungan antara tingkat literasi dan inklusi keuangan. Pemahaman mengenai literasi keuangan saja belum mampu dalam mendorong tingkat inklusi keuangan seseorang ataupun masyarakat. Dengan adanya dari modal sosial memberikan nilai-nilai positif dan dampak yang kuat untuk literasi dan inklusi keuangan.

\section{Gambar 2. Kerangka Pe mikiran}

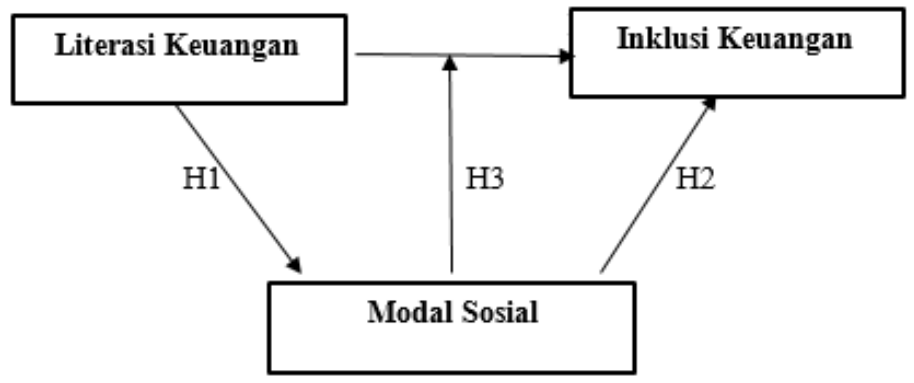

Sumber : Bongomin et.al (2016)

\section{Hipotesis}

H1 : Literasi Keuangan memiliki efek yang signifikan pada modal sosial

H2 : Modal Sosial memiliki efek yang signifikan terhadap modal sosial

H3 : Modal sosial memediasi hubungan yang signifikan antara literasi keuangan dan inklusi keuangan.

\section{METODE PENELITIAN}

\section{Sampel dan Populasi}

Populasi dari penelitian ini adalah seluruh masyarakat Kota Padang dengan total penduduk mencapai mencapai 5.382.077 jiwa pada tahun 2018 (www.sumbar.bps.go.id,2018). Penelitian ini dilaksanakan pada bulan September sampai dengan November 2018. Teknik pengambilan sampling yang digunakan adalah non-probability sampling dengan menggunakan rumus Slovin yaitu :

$$
n=\frac{N}{1+N e^{2}}
$$

Dimana :

n : Ukuran Sampel

$\mathrm{N}$ : Ukuran Populasi

e : 5\% (Konstanta kelonggaran ketidaktelitian karena kesalahan pengambilan keputusan sampel yang masih dapat ditolerir) 
Berdasarkan perhitungan dengan rumus Slovin didapat angka untuk sampel yaitu 399.825207 dan dibulatkan menjadi 400.

\section{Data Penelitian}

Penelitian ini menggunakan metode kuantitatif, menggunakan data primer yang didapatkan melalui penyebaran kuesioner dengan pengukuran skala likert's dimana setiap instrument pada kuesioner disertai lima kemungkinan jawaban yaitu poin (1) sangat tidak setuju, (2) tidak setuju, (3) netral, (4) setuju, dan (5) sangat tidak setuju. Kuesioner ini diadopsi dari penelitian sebelumnya dengan pertanyaan dalam variabel penelitian disesuaikan dengan keadaan objek penelitian. Sedangkan sumber data sekunder dari penelitian ini adalah berasal dari buku, jurnal, artikel website, berita online, penelitian sebelumnya, maupun sumber lain yang relevan.

\section{Variabel}

Variabel dalam penelitian ini diadopsi dari penelitian yang dilakukan oleh Bongomin et.al (2016) dimana setiap variable di turunkan kembali kembali menjadi sub-variabel. Variable inklusi keuangan dibagi menjadi empat sub-variabel yaitu welfare, quality, usage, dan access. Variable literasi keuangan dibagi menjadi empat sub-variable yaitu behaviour, skill, attitude, dan knowledge. Dan variable modal sosial dibagi menjadi empat sub-variable yaitu collective action, bonding, bridging, dan trust.

\section{Teknik Pengumpulan Data}

Teknik pengumpulan data dalam penelitian ini dengan menyebarkan kuesioner yang berisi daftar pertanyaan mengenai masalah yang diteliti. Kuesioner disebar kepada sampel yang telah ditentukan oleh peneliti yaitu penduduk Kota Padang. Sumber data pada penelitian ini adalah data sekunder yaitu Badan Pusat Statistik (BPS) sebagai sumber informasi resmi dari pemerintah mengenai populasi penduduk Kota Padang, dan sampel yang telah ditentukan sebagai sumber data primer.

\section{Teknik Analisis Data}

Metode analisis data yang digunakan adalah analisis deskriptif, analisis korelasi Pearson, uji asumsi klasik dan analisis mediasi menggunakan Baron and Kenny and Sobel Test untuk mengukur pengaruh langsung dan pengaruh tidak langsung. Untuk analisis deskriptif menggunakan rumus sebagai berikut :

Persentase $=\frac{\text { Nilai Kumulatif Item }}{\text { Nilai Frekuensi }} \times 100 \%$

Untuk analisis korelasi pearson menggunakan rumus :

$r=\frac{\sum X Y}{\sqrt{\left(\sum X^{2}\right)\left(\sum Y^{2}\right)}}$

Sedangkan untuk uji asumsi klasik menggunakan uji normalitas dan uji multikolinearitas. Untuk menguji pengaruh mediasi modal sosial dalam hubungan antara literasi keuangan dan inklusi keuangan, menggunakan rumus sebagai berikut:

$$
S a b=\sqrt{b^{2} s_{a}^{2}+a^{2} s_{b}^{2}+s_{a}^{2} s_{b}^{2}}
$$

Dimana :

$\mathrm{a}=$ variabel independen

$\mathrm{b}=$ variabel dependen 
$\mathrm{s}_{\mathrm{a}}=$ Standard error $\mathrm{a}$

$\mathrm{s}_{\mathrm{b}}=$ Standard error $\mathrm{b}$

Untuk menguji sobel $\mathrm{Z}$ adalah menggunakan rumus berikut :

$\mathrm{Z}=\frac{a b}{s_{a b}}$

Ketentuan untuk menghitung nilai $\mathrm{Z}$ yaitu, nilaiSobel $\mathrm{Z}$ akan signifikan jika > dari titik kritis efektivitas pengaruh mediasiyaitu 1,96 untuk tingkat signifikan 5\% dan 1,64 untuk tingkat signifikan $10 \%$ atau nilai $\boldsymbol{p}$ lebih kecil dari nilai signifikansi atau tingkat kepercayaan (Suhardi, 2009:8).

\section{HASIL PENELITIAN DAN PEMBAHASAN \\ Hasil Penelitian \\ Karakteristik Sampel}

Responden pada penelitian ini adalah masyarakat yang berdomisili di Kota Padang dan memiliki KTP Kota Padang. Pada penelitian ini pengumpulan data dilakukan dengan menyebarkan kuesioner kepada 400 responden secara online dan offline. Kuesioner yang disebar terdiri atas tiga bagian, bagian pertama merupakan screening question untuk menyaring responden sesuai kriteria pengisian kuesioner. Bagian kedua merupakan profil responden yang terdiri dari daftar pertanyaan untuk mengetahui karakteristik responden tersebut. Bagian ketiga berupa daftar pernyataan mengenai variabel-variabel dalam penelitian yaitu literasi keuangan, modal sosial dan inklusi keuangan. Berikut penggolongan responden berdasarkan karakteristik responden :

Tabel 1. Ka rakteristik Sampel

\begin{tabular}{|l|l|l|l|l|}
\hline No & Karakteristik & Klasifikasi & Jumlah Responden & \% \\
\hline 1 & Jenis & Laki-laki & 167 & $42 \%$ \\
& Kelamin & Perempuan & 233 & $58 \%$ \\
\hline 2 & Usia & $15-19$ & 43 & $10.75 \%$ \\
& & $20-24$ & 224 & $56 \%$ \\
& & $25-29$ & 39 & $9.75 \%$ \\
& & $30-34$ & 13 & $3.25 \%$ \\
& & $35-39$ & 8 & $2 \%$ \\
& & $40-44$ & 7 & $1.75 \%$ \\
& & $45-49$ & 20 & $5 \%$ \\
& & $50-54$ & 19 & $4.75 \%$ \\
& & $55-59$ & 20 & $5 \%$ \\
\hline 3 & Pendidikan & $>59$ & 7 & $1.75 \%$ \\
\hline & Terakhir & SD/MI & 6 & $1.50 \%$ \\
& & SMP/MTs & 11 & $2.75 \%$ \\
& & S1/D2/D3 & 199 & $49.75 \%$ \\
& & S1/D4 & 43 & $10.75 \%$ \\
& & S2 & 98 & $24.50 \%$ \\
& & S3 & 40 & $10 \%$ \\
& & Lainnya & - & $0.75 \%$ \\
& & & & - \\
\hline
\end{tabular}


Lanjutan Tabel 1. Karakteris tik Sampel

\begin{tabular}{|c|c|c|c|c|}
\hline No & Ka rakteristik & Klasifikasi & Jumlah Responden & $\%$ \\
\hline 4 & $\begin{array}{l}\text { Pendapatan } \\
\text { per bulan }\end{array}$ & $\begin{array}{l}\text { <p.1.000.001 } \\
\text { Rp.1.000.001- } \\
\text { Rp.2.500.000 } \\
\text { Rp.2.500.001 } \\
\text { Rp.4.000.000 } \\
\text { Rp.4.000.001 } \\
\text { Rp.5.500.000 } \\
\text { Rp.5.500.001 } \\
\text { Rp.7.000.000 } \\
>\text { Rp.7.000.000. }\end{array}$ & $\begin{array}{l}180 \\
69 \\
44 \\
41 \\
15 \\
51\end{array}$ & $\begin{array}{l}45 \% \\
17.25 \% \\
11 \% \\
10.25 \% \\
3.75 \% \\
12.75 \%\end{array}$ \\
\hline 5 & Pekerjaan & $\begin{array}{l}\text { Pelajar/Mahasiswa } \\
\text { Karyawan Swasta } \\
\text { PNS/BUMN } \\
\text { Wiraswasta } \\
\text { Lainnya }\end{array}$ & $\begin{array}{l}231 \\
25 \\
67 \\
26 \\
51\end{array}$ & $\begin{array}{l}57.57 \% \\
6.25 \% \\
16.75 \% \\
6.50 \% \\
12.75 \%\end{array}$ \\
\hline
\end{tabular}

Sumber : Hasil Penelitian, diolah (2018)

Berdasarkan tabel terlihat bahwa responden dengan jenis kelamin perempuan memiliki persentase yang lebih besar yaitu 58\%, ini sesuai dengan data penduduk di Kota Padang tahun 2016 yang menyatakan bahwa penduduk di Kota Padang lebih banyak berjenis kelamin perempuan, yaitu 914.180 jiwa berjenis kelamin laki-laki dan 915.756 jiwa berjenis kelamin perempuan. Rentang usia 20-24 tahun mendominasi pengisian kuesioner dengan persentase 56\%. Tingkat pendidikan terakhir yang ditempuh yaitu SMA/SMK/MA adalah tingkat pendidikan terakhir dengan persentase terbesar yaitu $49.75 \%$. Pendapatan perbulan <Rp.1.000.001 mendominasi pengisian responden dengan persentase $45 \%$. Pelajar/mahasiswa merupakan responden terbanyak pada penelitian ini yaitu sebesar $57.57 \%$.

\section{Analisis Deskriptif}

Analisis deskritif dilakukan guna memberikan gambaran tentang data berupa skor yang diperoleh oleh masing-masing dimensi dari setiap variabel dan pengkategorian dari setiap dimensi tersebut :

Tabel 2. Analisis Deskriptif

\begin{tabular}{|l|l|l|l|}
\hline Variabel & Sub Variabel & Persentase Skor & Kategori \\
\hline Literasi & Behaviour & $75.20 \%$ & Baik \\
& Skills & $76.23 \%$ & Baik \\
& Attitude & $66.05 \%$ & Netral \\
& Knowled ge & $79.60 \%$ & Baik \\
\hline Modal Sosial & Collective & $77.25 \%$ & Baik \\
& Action & $73.86 \%$ & Baik \\
& Bonding & $70.41 \%$ & Baik \\
& Bridging & $72.80 \%$ & Baik \\
& Trust & & \\
\hline
\end{tabular}


Lanjutan Tabel 2. Analisis Deskriptif

\begin{tabular}{|l|l|l|l|}
\hline Variabel & Sub Variabel & Persentase Skor & Kategori \\
\hline Inklusi & Welfare & $71.92 \%$ & Baik \\
Keungan & Quality & $72.35 \%$ & Baik \\
& Usage & $69.20 \%$ & Baik \\
& Access & $75.72 \%$ & Baik \\
\hline
\end{tabular}

Sumber : Hasil Penelitian, diolah (2018)

Berdasarkan tabel dapat dilihat bahwa semua dimensi pada variabel modal sosial dan inklusi keuangan termasuk pada kategori baik. Tiga dimensi pada variabel literasi keuangan termasuk pada kategori baik kecuali dimensi attitude yang termasuk pada kategori netral/cukup. Kategori didapatkan dari pengelompokan total nilai dibagi lima skala pengukuran, sehingga didapatkan rentang nilai sebesar $16 \%$. Dengan itu diperoleh rentang nilai 20\%-36\% : sangat tidak baik, 36\%-52\% : tidak baik, 52\%-68\% : netral, $68 \%-84 \%$ : baik dan $84 \%-100 \%$ : sangat baik. Hal ini berarti nilai dari literasi keuangan, inklusi keuangan dan modal sosial di Kota Padang dapat dikatakan baik.

\section{Analisis Korelasi Pearson}

Analisis korelasi pearson dilakukan untuk mengukur keeratan hubungan antara dua variabel yang mempunyai distribusi data normal. Berikut hasil output analisis korelasi pearson pada penelitian ini :

Tabel 3. Analisis Korelasi Pearson

Correlations

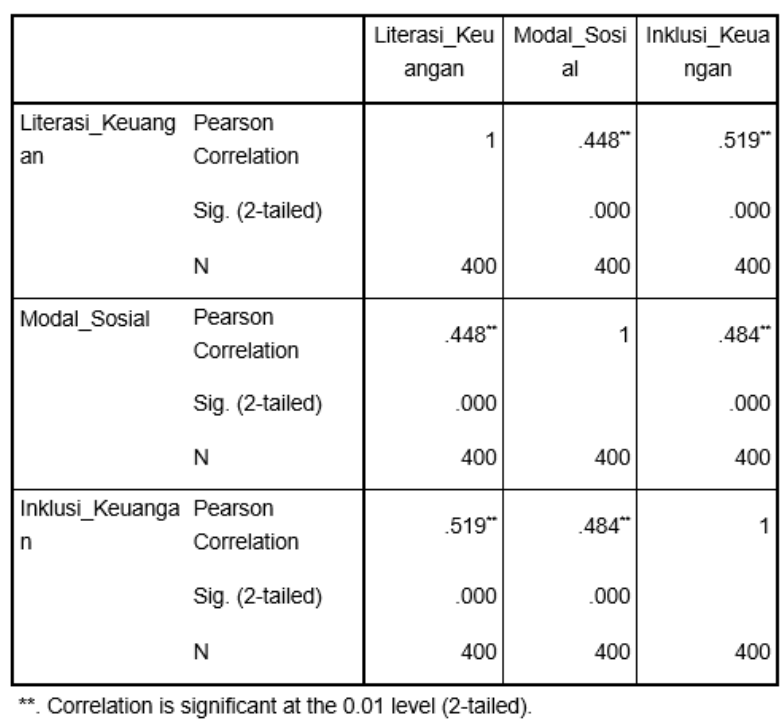

Sumber : Hasil Penelitian, diolah (2018)

Berdasarkan output dari analisis korelasi person disimpulkan bahwa terdapat korelasi antara setiap variabel dalam penelitian ini. Nilai $r$ korelasi antara literasi keuangan dengan modal sosial adalah sebesar 0.448 , nilai signifikansi 0.05 dengan nilai korelasi positif dan kekuatan sedang cenderung rendah. Nilai r korelasi antara literasi keuangan dan inklusi keuangan adalah sebesar 0.519 , nilai signifikansi 0.05 dengan nilai korelasi positif dan kekuatan sedang cenderung kuat. Nilai r korelasi antara modal sosial dengan inklusi keuangan adalah sebesar 0.484 , nilai signifikansi 0.05 dengan 
nilai korelasi positif dan kekuatan sedang cenderung rendah. Hal ini berarti jika seseorang memiliki tingkat literasi yang baik maka akan mempengaruhi partisipasi pada modal sosial, dan dengan adanya peningkatan pada partisipasi dalam modal sosial maka akan berpengaruh pada peningkatan inklusi keuangan.

\section{Uji Asumsi Klasik}

1. Uji Normalitas

\section{Gambar 3. Uji Normalitas}

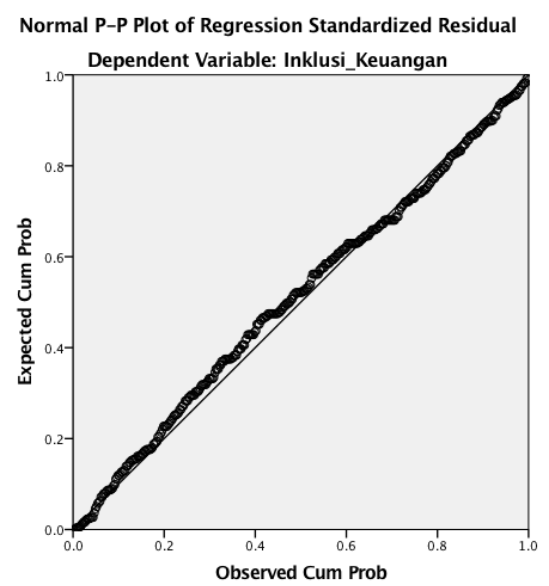

Sumber : Hasil Penelitian, diolah (2018)

Berdasarkan gambar 3 grafik normal P-P Plot pada uji normalitas dapat dilihat bahwa titik-titik yang ada mengikuti dan berada disekitar garis diagonal (cenderung naik) yang artinya data terdistribusi normal. Untuk mendukung hasil dari grafik P-P Plot, maka selanjutnya dilakukan uji normalitas residual, yaitu uji statistik nonparametrik, Kolomogorov-Smirnov, dapat dilihat pada tabel 4 berikut:

Tabel 4. Uji Kolmogorov-Smirnov One-Sample Kolmogorov-Smirnov Test

\begin{tabular}{|cc|c|}
\hline & & $\begin{array}{c}\text { Unstandardized } \\
\text { Residual }\end{array}$ \\
\hline Normal Parameters ${ }^{\mathrm{a}, \mathrm{b}} \quad$ Mean & 400 \\
& Std. Deviation & 4.79002578 \\
& Absolute & .059 \\
Most Extreme Differences & Positive & .042 \\
& Negative & -.059 \\
Kolmogorov-Smirnov Z & 1.173 \\
Asymp. Sig. (2-tailed) & .128 \\
\hline
\end{tabular}

a. Test distribution is Normal

b. Calculated from data

Sumber : Hasil Penelitian, diolah (2018)

Berdasarkan tabel 4 menunjukkan bahwa nilai signifikansi (Asymo.Sig 2-tailed) adalah sebesar 0.128. Karena nilai signifikansi >0.05 (0.128>0.05) maka dapat disimpulkan bahwa data yang diuji terd istribusi normal. 


\section{Uji Multikolinearitas}

Tabel 5. Uji Multikolinearitas

\begin{tabular}{|c|c|c|c|}
\hline \multirow{2}{*}{\multicolumn{2}{|c|}{ Model }} & \multicolumn{2}{|c|}{ Collinearity Statistics } \\
\hline & & Tolerance & VIF \\
\hline \multirow{3}{*}{1} & (Constant) & & \\
\hline & Literasi_keuangan & .800 & 1.250 \\
\hline & Modal_sosial & .800 & 1.250 \\
\hline
\end{tabular}

a. Dependent Variable: Inklusi_keuangan

Sumber : Hasil Penelitian, diolah (2018)

Uji multikolinearitas adalah untuk melihat ada atau tidaknya korelasi yang tinggi antara variabel-variabel bebas dalam suatu model regresi berganda. Jika terdapat korelasi yang tinggi diantara variabel bebas, maka hubungan antara variabel bebas terhadap variabel terikatnya akan terganggu. Untuk menguji adanya multikolinearitas dilihat menggunakan batas nilai toleransi atau tolerance value $>0,1$ atau nilai $\mathrm{VIF}<10$ maka tidak terjadi Multikolinearitas. Berdasarkan tabel 4 dapat dilihat bahwa variabel literasi keuangan memiliki nilai tolerance value sebesar $0.800>0.1$ dan nilai VIF sebesar $1.250<10$, Variable modal sosial nilai tolerance value sebesar $0.800>0.1$ dan nilai VIF sebesar $1.250<10$, berdasarkan hasil diatas maka dapat disimpulkan tidak terjadi multikolinearitas pada kedua variabel bebas pada penelitian ini.

\section{Analisis Mediasi}

Pada analisis ini akan diukur efek mediasi modal sosial pada hubungan antara literasi keuangan dan inklusi keuangan. Hasil dari perhitungan efek mediasi tersebut dijelaskan dalam tabel 6 berikut:

\section{Tabel 6. Hasil Efek Mediasi}

\begin{tabular}{|l|c|c|c|c|c|c|c|c|c|}
\hline \multirow{3}{*}{ Predictor } & \multicolumn{3}{|c|}{ Modal Sosial (M) } & \multicolumn{6}{c|}{ Inklusi Keuangan (Y) } \\
\cline { 2 - 11 } & \multicolumn{3}{|c|}{ Model 1 } & \multicolumn{3}{c|}{$\begin{array}{c}\text { Model 2 (Total Efect } \\
\text { Model) }\end{array}$} \\
\cline { 2 - 11 } & Coeff & SE & $\mathrm{p}$ & Coeff & SE & $\mathrm{p}$ & Coeff & SE & $\mathrm{p}$ \\
\hline & 28,5739 & 1,835 & 0,000 & 13,9022 & 1,5574 & 0,000 & 5,9119 & 1,8676 & 0.0017 \\
\hline $\begin{array}{l}\text { Lonstant } \\
\text { Keuangan }\end{array}$ & $\mathbf{0 , 6 8 4 6}$ & 0,0686 & 0,000 & $\mathbf{0 , 7 0 4 1}$ & 0,582 & 0,000 & $\mathbf{0 , 5 1 2 7}$ & 0.0615 & 0.000 \\
\hline $\begin{array}{l}\text { Modal } \\
\text { Sosial }\end{array}$ & & & & & & & $\mathbf{0 , 2 7 9 6}$ & 0.0402 & 0.000 \\
\hline
\end{tabular}

Sumber : Hasil Penelitian, diolah (2018)

Berdasarkan tabe15, maka dapat disimpulkan sebagai berikut :

Koefesien literasi keuangan pada modal sosial sebesar 0.6846 dengan $\mathrm{p}<0.05$, yang berarti bahwa terdapat efek yang signifikan antara literasi keuangan dan modal sosial. Berdasarkan hasil analisis maka $\mathrm{H} 1$ diterima yaitu literasi keuangan memiliki efek yang signifikan pada modal sosial.

Koefesien literasi keuangan terhadap inklusi keuangan pada model 2 adalah sebesar 0.7041 dengan $\mathrm{p}<0.05$, sedangkan koefesien literasi keuangan terhadap inklusi 
keuangan pada model 3 adalah sebesar 0.5167 dengan $\mathrm{p}<0.05$. Ini menandakan bahwa terdapat efek yang signifikan antara literasi keuangan dan inklusi keuangan pada model 2 maupun pada model 3.

Koefesien modal sosial pada inklusi keuangan sebesar 0.2769 dengan $\mathrm{p}<0.05$, yang berarti bahwa terdapat efek yang signifikan antara modal sosial dan inklusi keuangan. Berdasarkan hasil analisis maka $\mathrm{H} 2$ diterima yaitu modal sosial memiliki efek yang signifikan terhadap inklusi keuangan.

Berdasarkan hasil analisis efek mediasi, maka dapat disimpulkan bahwa penelitian ini telah memenuhi syarat untuk membangun mediasi yaitu pada persamaan pertama variabel independen memiliki efek pada variabel mediator, kemudian pada persamaan kedua variabel independen memiliki efek pada variabel dependen, dan pada persamaan ketiga variabel mediator memiliki efek pada variabel dependen.

Tahapan analisis selanjutnya melakukan uji sobel (Sobel Z Test) untuk menguji kekuatan pengaruh tidak langsung variabel independen $(X)$ terhadap variabel dependen (Y) melalui variabel intervening (M). Hasil dari perhitungan efek tidak langsung literasi keuangan pada inklusi keuangan melalui modal sosial dapat dilihat pada tabel berikut :

Tabel 7. Hasil Sobel Test

\begin{tabular}{|l|l|l|l|l|}
\hline \multicolumn{5}{|l|}{ Normal theory tests for indirect effect } \\
\hline Effect & Se & Z & p & $\begin{array}{l}\text { Effect } \\
\text { Size }\end{array}$ \\
\hline 0.1914 & 0.0282 & 5.7061 & 0.09272 & 0.1410 \\
\hline
\end{tabular}

Sumber : Hasil Penelitian, diolah (2018)

Berdasarkan tabel 6 dapat dilihat efek tidak langsung antara literasi keuangan terhadap inklusi keuangan dan melalui modal sosial adalah sebesar 0.1914, dengan nilai sobel $\mathrm{Z}$ sebesar 5.7061 dan nilai $\mathrm{p}$ value $<0.05$. Untuk lebih jelasnya dapat dilihat pada gambar 4 berikut :

\section{Gambar 4. Hasil Perhitungan Model Hipotesis}

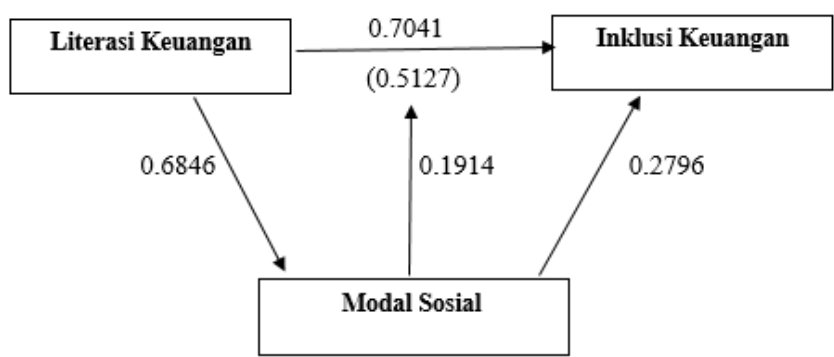

Sumber : Hasil Penelitian, diolah (2018)

Berdasarkan uji sobel test pada tabel 6 menunjukkan bahwa efek tidak langsung antara literasi keuangan dan inklusi keuangan namun melalui modal sosial adalah 0.1914 , sedangkan efek langsung antara literasi keuangan dengan inklusi keuangan adalah 0.5127. Nilai variabel mediator modal sosial dapat dilihat dari nilai effect size, yaitu 0.1410. Menurut Cohen (1988) nilai effect size dengan rentang $0.02-0.15$ termasuk dalam kategori lemah. Hasil sobel test pada tabel 6 juga menunjukkan hasil sobel Z yaitu 5.7061. Nilai Sobel Z untuk efek tidak langsung literasi keuangan pada inklusi keuangan melalui modal sosial akan signifikan jika > dari titik kritis efektivitas 
pengaruh mediasi yaitu 1,96 untuk tingkat signifikan 5\% (5.7061>1.96). Hasil analisis ini mempertegas bahwa variabel modal sosial memediasi variabel literasi keuangan dan inklusi keuangan secara partial pada masyarakat di Kota Padang.

\section{KESIMPULAN DAN SARAN \\ Kesimpulan}

Berdasarkan hasil penelitian dan pembahasan yang telah dilakukan, penelitian ini meneliti efek literasi keuangan pada modal sosial, efek modal sosial terhadap inklusi keuangan dan efek mediasi modal sosial terhadap literasi keuangan dan inklusi keuangan pada masyarakat di Kota Padang. Penelitian ini dilakukan dengan menyebarkan 400 kuesioner kepada masyarakat di Kota Padang secara acak baik secara online maupun offline.

Pada penelitian ini menemukan bahwa literasi keuangan memiliki efek yang signifikan pada modal sosial, modal sosial memiliki efek yang signifikan terhadap inklusi keuangan dan modal sosial mampu memediasi hubungan antara literasi keuangan dan inklusi keuangan secara partial pada masyarakat di Kota Padang.

\section{Saran}

1. Bagi Regulator

Regulator diharapkan dapat terus mengembangkan program-program yang telah dilaksanakan dan terus menambah program-program terkait untuk meningkatkan angka literasi keuangan dan inklusi keuangan di Kota Padang. Pemerintah juga hendaknya meningkatkan kerjasama dengan komunitas-komunitas atau perkumpulan yang berhubungan dengan jasa keuangan agar dapat meningkatkan peranan modal sosial dalam memediasi hubungan antara literasi keuangan dan inklusi keuangan.

2. Bagi Masyarakat/Komunitas

Komunitas-komunitas/perkumpulan di masyarakat hendaknya menjadi penggerak dan menjadi peran penting dalam meningkatkan angka literasi keuangan dan inklusi keuangan di Kota Padang khususnya dan Indonesia. Kominutas dapat memperluas jaringannya dengan cara bekerja sama dengan komunitas lainnya ataupun bekerja sama dengan pemeritahan dan lembaga terkait untuk memperoleh informasi serta edukasi lebih mengenai produk dan jasa keuangan.

3. Bagi Peneliti Selanjutnya

Objek penelitian pada penelitian ini adalah masyarakat Kota Padang secara umum. Untuk penelitian selanjutnya lebih baik apabila menjadikan objek penelitian menjadi lingkup yang lebih kecil seperti masyarakat dengan rentang usia tertentu, masyarakat yang memiliki penghasilan rendah, masyarakat dengan tingkat pendidikan rendah ataupun menjadikan kota-kota besar lainnya. Peneliti selanjutnya juga dapat meneliti variabel-variabel mediasi lainnya yang lebih signifikan dalam membantu memediasi hubungan antara literasi keuangan dan inklusi keuangan. Penelitian ini merupakan penelitian kuantitatif dengan menggunakan kuesioner sebagai alat pengumpulan data, penelitian selanjutnya dapat menggunakan metode kualitatif dengan menggunakan metode wawancara langsung untuk memperoleh data yang diperlukan. Penelitian ini juga termasuk pada penelitian dengan tipe waktu 
pelaksaan cross sectional dikarenakan keterbatas waktu, peneliti selanjutnya diharapkan dapat menggunakan metode longitudinal.

\section{DAFTAR PUSTAKA}

Badan Pusat Statistik Provinsi Sumatera Barat. 2018. Penduduk Provinsi Sumatera Barat, 2000-2018. [online]. https://sumbar.bps.go.id/dynamictable/2017/05/16/101/penduduk-provinsisumatera-barat-2000-2018.html. [10 Agustus 2018].

Baron, R.M. \& Kenny, D.A. 1986. The Moderator-Mediator Variable Distinction in Social Psychological Research: Conceptual, Strategic, and Statistical Considerations. Journal of personality and Social Psychology. 51 (6), 1173-1182. BI. 2018. Keuangan Inklusif di Indonesia. [online].

http://www.bi.go.id/id/perbankan/keuanganinklusif/program/Contents/default. aspx. [02 Maret 2018]

Bongomin et al. 2016. Social Capital : Mediator of Financial Literacy and Financial Inclusion in Rural Uganda. Review of International Business and Strategy. 26(2). 291-312.

http://www.bi.go.id/id/perbankan/keuanganinklusif/program/Contents/default.aspx. [02 Maret 2018]

Cohen, J. 1988. Statistical Power Analysis for the Behavioral Sciences (2nd ed.). Hillsdale N.J.: L. Erlbaum Associates.

Felicio, J Augusto et, al. 2014. Human Capital, Sosial Capital, and Organizational Performance. Management Decision. 2(52). 350-364.

Hung, et.al. 2009. Defining and Measuring Financial Literacy. RAND Labor and Population Working Paper Series. WR-708.

Kamukama, Nixon dan Natamba, Bazinzi. 2013. Social Capital : Mediator of Social Intermediation and Financial Services Access. International Journal of Commerce and Management. 3(23). 204-215.

Otoritas Jasa Keuangan. 2016. Literasi Keuangan. [online]. https://www.ojk.go.id/id/kanal/edukasi-dan-perlindungankonsumen/Pages/Literasi-Keuangan.aspx . [3 Desember 2016]

Otoritas Jasa Keuangan. 2016. Survey Nasional Literasi dan Inklusi Keuangan 2016. [online]. https://www.ojk.go.id/id/berita-dan-kegiatan/siaranpers/Documents/Pages/Siaran-Pers-OJK-Indeks-Literasi-dan-Inklusi-Keuangan Meningkat/17.01.23\%20Tayangan\%20\%20Presscon\%20\%20nett.compressed.pdf . [3 Desember 2016]

Padangkita.com. 2018. Tingkat Literasi dan Inklusi Keuangan Masyarakat Sumbar Masih Di Bawah Nasional. [online]. <http://padangkita.com/tingkat-literasi-daninklusi-keuangan- masyarakat-sumb ar-masih-di-bawah-nasional/>.[3 Desember 2016]

Rasyid, Rosyeni. 2012. ' Analisis Tingkat Literasi Keuangan Mahasiswa Program Studi Manajemen Fakultas Ekonomi Universitas Negeri Padang', Jurnal Kajian Manajemen Bisnis, Vol. 1, No. 2.

Saputra, Rachmat Simbara \& Dewi, Andrieta Shintia. 2017. Peran Modal Sosial Sebagai Mediator Literasi Keuangan Dan Inklusi Keuangan Pada Kaum Muda 
Di Indonesia (Studi Kasus Pada Komunitas Investor Saham Pemula). Jurnal Manajemen Teori Dam Terapan, Tahun 10, No. 3.

Suhardi, Deddy A. 2009. Efektivitas Variabel Mediator Berdasarkan Kontribusinya dalam Model Mediasi Sederhana. Jurnal Matematika, Sains, dan Teknologi. 1(9). 6-17.

Yanti, Novera Fitri. 2017. Modal Sosial Pada Usaha Rubik Ganepo Di Jorong Padang Kandi Nagari VII Koto Talago Kecamatan Guguak Kabupaten Lima Puluh Kota. JOM FISIP, Vol. 4, No. 3. 